객담 도말 양성 환자에서 폐결핵과 비결핵 항산균 폐질환의 구별을 위한 결핵균 $\mathrm{PCR}$ 검사의 유용성

\author{
성균관대학교 의과대학 내과학교실, ${ }^{1}$ 삼성서울병원 호흡기내과, 진단검사의학과 ${ }^{2}$

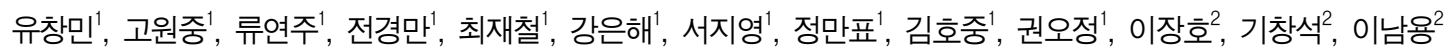

\title{
Usefulness of PCR Test for $M$. tuberculosis for the Differentiation of Pulmonary Tuberculosis and Nontuberculous Mycobacterial Lung Disease in Patients with Smear-Positive Sputum
}

Chang-Min Yu, M.D.', Won-Jung Koh, M.D.', Yon Ju Ryu, M.D.', Kyeongman Jeon, M.D.', Jae Chol Choi, M.D.', Eun Hae Kang, M.D.', Gee Young Suh, M.D.', Man Pyo Chung, M.D.', Hojoong Kim, M.D.', O Jung Kwon, M.D.', Jang Ho Lee, M.T.', Chang-Seok Ki, M.D., Nam Yong Lee, M.D. ${ }^{2}$

${ }^{1}$ Division of Pulmonary and Critical Care Medicine, Department of Medicine and ${ }^{2}$ Laboratory Medicine, Samsung Medical Center, Sungkyunkwan University School of Medicine, Seoul, Korea

Background : Microscopic examination of sputum smears for acid-fast bacilli (AFB) is the most important and rapid diagnostic test for pulmonary tuberculosis. However, the AFB observed on the smear may represent either $M$. tuberculosis or nontuberculous mycobacteria (NTM). This study examined the clinical usefulness of a polymerase chain reaction test for $M$. tuberculosis (TB-PCR) for the differentiation of pulmonary tuberculosis and NTM lung disease in patients with smear-positive sputums in a tertiary hospital in Korea.

Material and Methods : From January, 2003 to December, 2003, 826 AFB smear-positive and culture-positive sputum specimens were collected from 299 patients.

Results : NTM were recovered from 26.6\% (220/826) of the smear-positive sputum specimens and 23.4\% (70/299) of the patients with smear-positive sputum. All the patients with isolated NTM had clinically significant NTM lung disease; 38 patients (54.3\%) had M. avium and 26 patients (37.1\%). had M. abscessus. In the patients with pulmonary tuberculosis, $78.7 \%$ of the patients (74/94) showed TB-PCR positivity, and all the patients with NTM lung disease showed negative results on the TB-PCR test $(p<0.001)$. A positive result of the TB-PCR test on the sputum or bronchial washing fluid specimens was able to predict pulmonary tuberculosis with $88.4 \%$ sensitivity, $100 \%$ specificity, a 100\% positive predictive value and a 79.7\% negative predictive value for the patients with smear-positive sputum.

Conclusion : The TB-PCR test for sputum specimens or bronchial washing fluid specimens could be useful for differentiating pulmonary tuberculosis and NTM lung disease for the patients with smear-positive sputum in Korea. (Tuberc Respir Dis 2004: 57:528-534)

Key words : Mycobacterium tuberculosis, Atypical mycobacteria, Polymerase chain reaction, Korea

\section{서 론}

폐결핵은 결핵균(Mycobacterium tuberculosis)에 의해 발생하는 질병으로 폐결핵의 진단은 호흡기 검

Address for correspondence : Won-Jung Koh, M.D. Division of Pulmonary and Critical Care Medicine, Department of Medicine, Samsung Medical Center, Sungkyunkwan University School of Medicine, 50 Ilwon-dong, Kangnam-ku, Seoul 135-710, Korea. Phone : (822) 3410-3429 Fax : (822) 3410-3849 E-mail : wjkoh@smc.samsung.co.kr

Received : Aug. 31. 2004

Accepted : Dec. 7. 2004
체로부터 세균학적으로 결핵균을 배양하여 검출하는 것이 가장 확실한 방법이다 ${ }^{1}$. 그러나 결핵균 배양검사 는 오랜 시간이 필요하다는 단점이 있어 객담 항산균 도말 검사가 폐결핵의 진단에서 가장 중요한 검사로 여겨지고 있다 ${ }^{2,3}$. 객담 도말 검사는 저렴하고 간편한 검사이며, 검사 결과를 빨리 얻을 수 있어 환자 관리 에 편리하다. 또한 도말 검사로 찾아내는 환자는 배균 량이 많은 환자이기 때문에 배양 양성 환자보다는 감 염 위험이 높아 역학적으로도 매우 중요하다.

하지만 항산균 도말 검사는 결핵균과 비결핵 항산 균(nontuberculous mycobacteria, NTM)을 구별할 수 
없다는 제한점을 가지고 있다 ${ }^{1,4}$. 한편 중합효소연쇄반 응을 이용한 결핵균에 대한 핵산증폭검사(polymerase chain reaction test for $M$. tuberculosis, TB-PCR)는 도말 양성 검체에서 결핵균을 확인하는 민감도와 특 이도가 매우 높아 ${ }^{4,5}, \mathrm{NTM}$ 폐질환의 빈도가 높은 미 국의 경우 객담 항산균 도말 양성을 보인 경우에는 TB-PCR을 시행하여 양성을 보일 때는 폐결핵으로 잠정 진단하고, 음성을 보일 때는 NTM에 감염된 것 으로 잠정 진단 후 최종 진단은 배양 결과를 가지고 판단하도록 권장하고 있다 ${ }^{1,6}$.

이에 비해 우리나라에서는 현재까지 객담 항산균 도말 양성이 폐결핵의 확실한 진단기준으로 사용되고 있다 ${ }^{3,7}$. 이는 우리나라는 폐결핵에 비하여 NTM 폐질 환의 빈도가 외국에 비해 상대적으로 낮을 것으로 판 단하였기 때문일 것이나, 최근 연구에서는 국내에서 도 항산균 도말 양성 환자의 $10 \%$ 이상에서 결핵균이 아닌 NTM이 분리되어 국내에서 진단되는 도말 양성 폐결핵 환자의 일부가 사실은 폐결핵이 아닌 NTM 폐질환일 수 있음을 시사하였다 ${ }^{8}$.

국내에서는 임상적으로 폐결핵이 의심되지만 객담 도말 음성인 환자에서 폐결핵을 진단하기 위하여 객 담 ${ }^{9-11}$ 또는 기관지 세척 액,12-14을 이용한 TB-PCR 검 사의 유용성에 대해서는 여러 연구가 있어왔다. 하지 만 객담 도말 양성 환자에서 폐결핵과 NTM 폐질환 을 감별하기 위한 TB-PCR 검사의 유용성에 대해서 는 아직까지 보고된 바 없었다. 본 연구는 국내에서도 객담 도말 양성 환자에서 폐결핵과 NTM 폐질환을 감별하기 위해서 $\mathrm{TB}-\mathrm{PCR}$ 검사가 유용한 지에 대해 알아보고자 하였다.

\section{대상 및 방법}

2003년 1월 1일부터 2003년 12월 31일까지 1년간 진단검사의학과 임상미생물검사실로 항산균 도말 및 배양검사가 의뢰된 객담 검체 중 도말과 배양이 모두 양성인 826건의 객담 검체를 연구대상으로 하였다. 826건의 도말 양성, 배양 양성 객담은 299명의 환자로 부터 분리되었으며, 이 환자들의 의무기록과 방사선 학적 소견을 후향적으로 조사하였다.
객담 항산균 도말 검사는 carbol-fuchsin을 이용한 Ziehl-Neelsen 염색법을 이용하였다. 도말 검사 결과 는 정량적으로 판정하였다. 300 시야에서 $\mathrm{AFB}$ 가 관 찰되지 않으면 음성, 300 시야에서 $\mathrm{AFB}$ 가 1-2개 관찰 되면 trace, 100 시야에서 $\mathrm{AFB}$ 가 1-9개 관찰되면 1+, 10 시야에서 $\mathrm{AFB}$ 가 $1-9$ 개 관찰되면 2+, 한 시야에서 $\mathrm{AFB}$ 가 1-9개 관찰되면 $3^{+}$, 그리고 한 시야에서 $\mathrm{AFB}$ 가 10 개 이상 관찰되면 $4+$ 로 판정하여, $1+$ 이상을 도 말 양성으로 정의하였다.

객담 검체에서 오염균 제거를 위한 전처치는 $\mathrm{N}-$ acetyl-L-cystein $2 \% \mathrm{NaOH}$ 처리법을 사용하였다. 배 양검사를 위한 고체배지는 3\% Ogawa 배지를 이용하 였고, 1 주일에 한번씩 배지를 관찰하여 균주의 성장여 부를 확인하였고 최종적으로 8주까지 배양한 후 결과 를 판정하였다. 배양된 균주는 증식속도와 집락의 색, 집락의 형태 그리고 Mycobacterium tuberculosis Direct test (MTD; Gen-Probe Inc, San Diego, CA, $\mathrm{USA}$ )를 이용하여 결핵균과 $\mathrm{NTM}$ 을 구별하였다 ${ }^{1}$. $\mathrm{NTM}$ 균 동정은 $r p o B$ 유전자를 목표로 한 polymerase chain reaction-restriction fragment length polymorphism analysis (PCR-RFLP) 방법 ${ }^{15}$ 을 사용하여 대 한결핵협회 결핵연구원에서 시행하였다.

객담에서 결핵균이 분리된 환자는 폐결핵으로 진단 하였다. 결핵균이 분리되지 않고 NTM이 분리된 환자 는 미국흥부학회의 NTM 폐질환 진단기준에 따라 첫 째, 미국흥부학회의 임상적, 방사선학적, 미생물학적 진단기준을 모두 만족하는 NTM 폐질환 군(definite NTM pulmonary disease)과 임상적, 방사선학적 진단 기준을 만족하지만 1 회의 객담 검사에서만 항산균 도 말 양성, NTM 배양 양성을 보여 미생물학적 기준을 충족하지 못하는 환자는 NTM 폐질환의 가능성이 높 은 군(probable NTM pulmonary disease)으로 분류하 였으며, 이 두 군을 임상적 의의가 있는 NTM 폐질환 군(clinically significant NTM pulmonary disease)으 로 정의하였다 ${ }^{16}$.

객담 또는 기관지 세척액에서의 $\mathrm{TB}-\mathrm{PCR}$ 검사는 AMPLICOR Mycobacterium tuberculosis test (Roche Diagnostic Systems, Inc., Branchburg, NJ, USA)를 사용하여 제조회사의 지침에 따라 시행하였다. 
통계분석은 Windows용 SPSS 프로그램(SPSS Release 10.0, SPSS Inc, Chicago, IL, USA)을 이용하여 실시 하였다. 폐결핵과 NTM 폐질환에서 TB-PCR 검사 양 성률의 차이는 chi-square test로 비교하였다. 유의수 준은 0.05 로 하였다.

\section{결 과}

\section{1. 항산균 도말 양성 환자 중 폐결핵과 NTM 폐질환의 비율}

299명의 환자에서 시행된 826건(중앙값 2회, 범위 1-15회)의 객담검사가 항산균 도말 양성, 배양양성을 보였다. 이중 결핵균이 분리된 객담은 606건(73.4\%), $\mathrm{NTM}$ 이 분리된 객담은 220 건(26.6\%)이었다. 299명의 환자 중 229 명 $(76.6 \%)$ 의 환자에서는 결핵균이 분리되 었고, 70 명 $(23.4 \%)$ 의 환자에서는 NTM이 분리되었다. 항산균 도말 양성 객담에서 $\mathrm{NTM}$ 이 분리된 환자 70 명 중 63명은 미국흥부학회의 NTM 폐질환 진단기준 을 모두 만족하는 NTM 폐질환 환자였으며, 7명은 $\mathrm{NTM}$ 폐질환의 가능성이 높은 환자였다. NTM 폐질 환의 원인균은 $M$. avium complex가 38명(54.3\%), $M$. abscessus가 26명(37.1\%) 기타 6명 등이었다 (Table 1).

\section{2. 객담 $\mathrm{TB}-\mathrm{PCR}$ 검사 결과}

객담 검체를 이용한 $\mathrm{TB}-\mathrm{PCR}$ 검사는 폐결핵 환자 229 명 중 94명(41.0\%)와 NTM 폐질환 환자 70명 중 44명(62.9\%)에서 시행되었다. 검사를 시행한 폐결핵 환자 94 명 중 74 명 (78.7\%)에서 $\mathrm{TB}-\mathrm{PCR}$ 검사가 양성 을 보였고, NTM 폐질환 환자는 모두 음성을 보였다 ( $<<0.001)$, 객담 도말 양성 환자에서 객담 $\mathrm{TB}-\mathrm{PCR}$
Table 1. Final diagnosis of 299 patients with smearpositive sputum

\begin{tabular}{lc}
\hline Diagnosis & Number of patients \\
\hline Pulmonary tuberculosis & $229(76.6 \%)$ \\
NTM lung disease & $70(23.4 \%)$ \\
M. avium complex & 38 \\
M. abscessus & 26 \\
M. kansasii & 3 \\
M. chelonae & 2 \\
M. celatum & 1 \\
\hline Total & $299(100 \%)$ \\
\hline * nontuberculous mycobacteria &
\end{tabular}

검사 양성 반응이 폐결핵을 예측하는 민감도와 특이 도는 각각 $78.7 \%(74 / 94)$ 와 $100 \%(44 / 44)$ 였고, 양성 예 측치는 $100 \%(74 / 74)$ 그리고 음성 예측치는 $68.8 \%(44 /$ 64)였다 (Table 2).

\section{3. 기관지 세척액 $\mathrm{TB}-\mathrm{PCR}$ 검사 결과}

기관지내시경을 통해 얻은 기관지 세척액을 이용한 TB-PCR 검사는 폐결핵 환자 229명 중 48명(21.0\%) 와 NTM 폐질환 환자 70 명 중 34 명(48.6\%)에서 시행 되었다. 검사를 시행한 폐결핵 환자 48 명 중 43 명 (89.6\%)에서 TB-PCR 검사가 양성을 보였고, NTM 폐질환 환자는 모두 음성을 보였다 $(\mathrm{p}<0.001)$. 객담 도말 양성 환자에서 기관지 세척액 TB-PCR 검사 양 성 반응이 폐결핵을 예측하는 민감도와 특이도는 각 각 89.6\%(43/48)와 $100 \%(34 / 34)$ 였고, 양성 예측치는 $100 \%(43 / 43)$ 그리고 음성 예측치는 $87.2 \%(34 / 39)$ 였다 (Table 3).

\section{4. 객담과 기관지 세척액 $\mathrm{TB}-\mathrm{PCR}$ 검사 결과의 종합}

위 결과를 종합하면 폐결핵 환자 229 명 중 112 명 (48.9\%)와 NTM 폐질환 환자 70명 중 51명(72.9\%)에

Table 2. The results of the sputum TB-PCR test

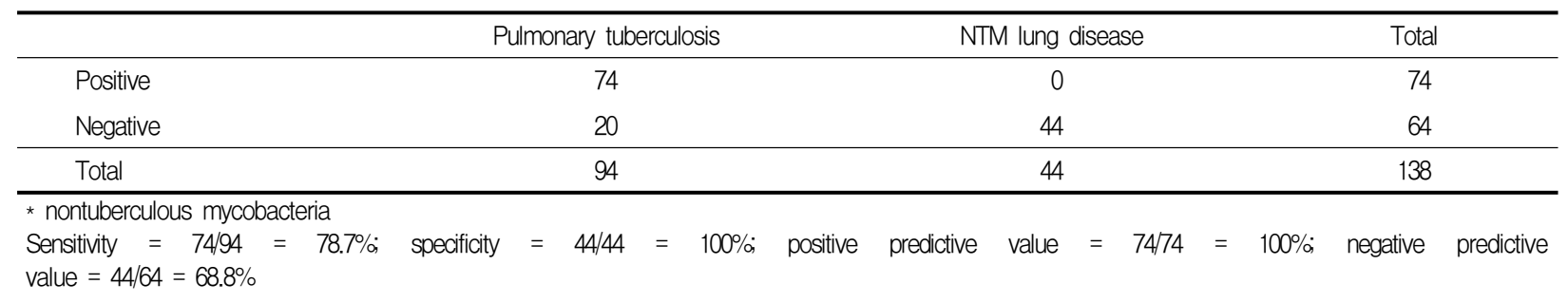


Table 3. The results of bronchial washing fluid TB-PCR testing

\begin{tabular}{lccc}
\hline & Pulmonary tuberculosis & NTM lung disease & Total \\
\hline Positive & 43 & 0 & 43 \\
Negative & 5 & 34 & 39 \\
\hline Total & 48 & 34 & 82 \\
\hline nontuberculous mycobacteria & Sensitivity $=43 / 48=89 \%$ specificity $=34 / 34=100 \%$ positive predictive value $=43 / 43=100 \%$ negative predictive \\
value $=34 / 39=87.2 \%$
\end{tabular}

Table 4. The results of TB-PCR for all the respiratory specimens

\begin{tabular}{|c|c|c|c|c|c|c|c|}
\hline & Pulmona & ary tuberculosis & & & NTM lung disease & & Total \\
\hline Positive & & 99 & & & 0 & & 99 \\
\hline Negative & & 13 & & & 51 & & 64 \\
\hline Total & & 112 & & & 51 & & 163 \\
\hline
\end{tabular}

서 객담 또는 기관지 세척액을 이용한 TB-PCR 검사 가 시행되었다. 검사를 시행한 폐결핵 환자 112 명 중 99명(88.4\%)에서 TB-PCR 검사가 양성을 보였고, $\mathrm{NTM}$ 폐질환 환자는 모두 음성을 보였다 $(\mathrm{p}<0.001)$. 객담 도말 양성 환자에서 객담 또는 기관지 세척액의 $\mathrm{TB}-\mathrm{PCR}$ 검사 양성 반응이 폐결핵을 예측하는 민감 도와 특이도는 각각 $88.4 \%(99 / 112)$ 와 $100 \%(51 / 51)$ 였 고, 양성 예측치는 100\%(99/99) 그리고 음성 예측치는 79.7\%(51/64)였다 (Table 4).

\section{고 찰}

결핵의 적절한 관리를 위해서는 무엇보다도 결핵 환자를 조기에 진단하여 치료를 시작하는 것이 중요 하다. 이를 위해서 가장 중요한 검사는 객담 항산균 도말 검사로 이는 저렴하고 간편한 검사이며, 검사 결 과를 빨리 얻을 수 있다는 장점이 있지만, 결핵균과 $\mathrm{NTM}$ 을 구별하지 못한다는 단점이 있다 ${ }^{1,4}$.

우리나라의 국가결핵관리사업에서는 환자발견을 위 한 검사로 흉부방사선촬영과 객담검사를 시행하고 있 으며, 흥부방사선촬영에서 폐결핵이 의심되는 환자는 2 회의 객담을 수집하여 도말 검사를 시행하고, 2 회의 도말 검사 결과가 모두 음성일 때는 1 회 배양 검사를 시행하도록 하고 있다 ${ }^{7}$. 대한결핵 및 호흡기학회에서 는 객담 도말 검사는 2 회 또는 3 회 실시를 원칙으로
하며, 계속 도말 음성인 경우에는 배양검사를 시행하 도록 권장하고 있다. 만약 객담 도말 검사에서 2회 이 상 양성이거나, 1 회 양성이면서 흉부방사선촬영상 폐 결핵에 합당한 이상 소견이 있으면 도말 양성 폐결핵 으로 진단하도록 하였다 ${ }^{3,7}$. 즉, 배양 검사를 통해 결핵 균을 반드시 확인하지 않더라도 객담 도말 양성인 경 우 폐결핵으로 진단하고 있으며 아직까지는 NTM 폐 질환의 가능성을 크게 고려하지 않고 있다는 것을 알 수 있다.

하지만 최근 연구에서는 항산균 도말 양성, 배양 양 성 검체의 $7.3 \%$ (대한결핵협회 결핵연구원)에서 $10.3 \%$ (삼성서울병원)에서 결핵균이 아닌 NTM이 분리되었 다고 보고되어 국내에서도 도말 양성 폐결핵으로 진 단받은 환자의 일부가 폐결핵이 아닌 NTM 폐질환일 수 있음을 시사하였다. 또한 도말 음성 검체까지 합 할 경우 1990년 이후 몇몇 대학병원에서는 임상 검체 에서 분리되는 항산균 중 NTM이 차지하는 비율이 20-30\%에 이르고 있다는 것이 확인되어 국내에서도 폐결핵과 NTM 폐질환의 감별이 임상에서 현실적인 문제가 되고 있음을 보여주었다 8 .

도말 양성 환자에서 폐결핵과 NTM 폐질환의 감별 이 필요한 경우에 이를 구별할 수 있는 방법으로는 $\mathrm{TB}-\mathrm{PCR}$ 검사가 추천되고 있다 ${ }^{1,4,5} . \mathrm{TB}-\mathrm{PCR}$ 검사가 도말 양성 검체에서 결핵균을 검출하는 민감도는 현 재까지의 여러 연구를 종합하면 90-100\%에 이르며, 
특이도는 $95-100 \%$ 에 이르고 있다 $1,5,17$. 이에 반해 $\mathrm{TB}-\mathrm{PCR}$ 검사가 도말 음성 검체에서 결핵균을 검출 하는 특이도는 $95 \%$ 에 이르지만, 민감도는 $50 \%$ 내외 에 불과하다 ${ }^{1,5,17}$. 이러한 이유로 미국 식품의약품안 전청(Food and Drug Administration)에서는 1996년 AMPLICOR M. tuberculosis test (Roche)와 GenProbe MTD test (Gen-Probe)를 도말 양성 호흡기 검 체에서만 사용할 수 있도록 허가하였다 ${ }^{18}$. 이후 1999 년 미국 식품의약품안전청은 진단방법이 개선된 $\mathrm{re}^{-}$ formulated Amplified M. tuberculosis Direct test (AMTD) (Gen-Probe)를 폐결핵이 의심되지만 도말 음성인 환자에서도 사용할 수 있도록 허가하였다. 이 에 따라 2000년 미국 질병관리본부(Centers for Disease Control and Prevention)는 결핵이 의심되는 환자에서 는 3회의 객담 도말과 배양검사와 함께 $\mathrm{TB}-\mathrm{PCR}$ 검 사를 시행하여, 도말 양성 환자에서 $\mathrm{TB}-\mathrm{PCR}$ 검사가 양성을 보일 때는 폐결핵으로 잠정 진단하고, $\mathrm{TB}^{-}$ $\mathrm{PCR}$ 검사에서 음성을 보일 때는 NTM에 감염된 것 으로 잠정 진단 후 최종 진단은 배양결과를 가지고 판 단하도록 권장하였다.

본 연구는 국내에서도 객담 항산균 도말 환자에서 TB-PCR 검사가 폐결핵과 NTM 폐질환을 구별하는 데 도움이 될 수 있음을 확인하였다. 본 연구에서는 객담 도말 양성 환자에서 객담 또는 기관지 세척액 TB-PCR 검사가 양성을 보이는 경우 위양성률은 $0 \%$ 로 폐결핵을 예측하는 양성 예측도는 $100 \%$ 였지만, TB-PCR 검사가 음성을 보이는 경우 폐결핵이 아닌 NTM 폐질환일 가능성은 $80 \%$ 였다. 따라서 이러한 결 과에 따르면 객담 도말 양성이지만 $\mathrm{TB}-\mathrm{PCR}$ 검사가 음성인 경우는 폐결핵보다는 NTM 폐질환의 가능성 이 더 높다고 할 수 있을 것이다. 하지만 이는 도말 양 성 환자에서 $\mathrm{TB}-\mathrm{PCR}$ 검사가 음성이라도 실제로는 폐결핵일 가능성이 $20 \%$ 에 달하는 것으로, 이는 $\mathrm{TB}^{-}$ $\mathrm{PCR}$ 검사의 민감도가 $88 \%$ 로 이전에 보고된 도말 양 성 환자에서의 민감도 90-100\% $\%^{1,5,17}$ 에 비해 낮은 수치 이기 때문이다. 이러한 낮은 민감도는 객담 TB-PCR 검사방법과 관련되었을 가능성이 있다. 환자로부터 여러 차례 채취한 객담의 질은 각각의 객담에 따라 다 를 수 밖에 없으며, 항산균 도말 양성 환자를 대상으
로 한 연구에서도 첫 객담에서 71-86\%가 도말 양성을 보이고, 첫 객담에서 도말 음성을 보이는 경우 두 번 째 객담에서 10-17\%, 세 번째 객담에서 5-8\%가 추가 로 도말 양성을 보인다 ${ }^{19-21}$. 따라서 미국 질병관리본 부는 폐결핵이 의심되는 환자에서 시행한 3 회의 객담 도말에서 도말 음성인 경우는 첫 번째 객담에서 그리 고 도말 양성인 경우는 그 검체에서 $\mathrm{TB}-\mathrm{PCR}$ 검사를 시행하도록 권장하고 있다. 하지만 본 연구의 대상기 간에는 도말 양성 검체에서 직접 $\mathrm{TB}-\mathrm{PCR}$ 검사를 시 행하지 않고 별도로 채취한 검체에서 $\mathrm{TB}-\mathrm{PCR}$ 검사 를 시행하였기 때문에, 실제로는 TB-PCR 검사를 시 행한 검체가 도말 양성 검체가 아닐 가능성이 있으며 이것이 민감도를 낮춘 원인이 되었을 것이며, 이는 본 연구의 제한점이 될 것이다. 91 명의 객담 도말 양성 환자를 포함한 107 명의 폐결핵 환자를 대상으로 조사 한 한 국내 연구에서도 객담 $\mathrm{TB}-\mathrm{PCR}$ 검사의 누적 양 성률이 1 회 검사에서 $89 \%, 2$ 회 검사에서 $95 \%, 3$ 회 검 사에서 $98 \%$, 그리고 4회 검사에서 $100 \%$ 증가하였다 고 하여, 본 연구와 유사한 1 회 검사에서의 $\mathrm{TB}-\mathrm{PCR}$ 검사 양성률을 보고하였다 ${ }^{10}$. 도말 양성 환자에서 폐 결핵과 NTM 폐질환을 구별하기 위한 TB-PCR 검사 의 민감도를 높이기 위해서는 2 회 또는 3 회 채취한 검 체 중 도말 양성 검체에서 직접 $\mathrm{TB}-\mathrm{PCR}$ 검사를 시행 하는 노력이 필요할 것으로 사료된다. 또한 TB-PCR 검사를 시행한 검체가 실제로는 도말 양성 검체가 아 닐 가능성은 NTM 폐질환 환자에서도 발생하였을 가 능성이 있다. 하지만 이러한 검체의 문제가 폐결핵 환 자와 NTM 폐질환 환자에서 동일한 비율로 발생하였 을 것으로 가정한다면, 본 연구결과의 양성 예측치와 음성 예측치는 달라지지 않을 것이다.

무엇보다도 본 연구의 가장 큰 제한점은 연구기간 동안 객담 도말 양성 환자 모두에서 $\mathrm{TB}-\mathrm{PCR}$ 검사가 시행되지 않았다는 점이다. 폐결핵 환자의 $49 \%, \mathrm{NTM}$ 폐질환 환자의 $73 \%$ 에서만 객담 또는 기관지 세척액 의 TB-PCR 검사가 시행되었기 때문에 본 연구의 결 과를 바로 일반화할 수는 없을 것이다. 또한 본 연구 의 대상기간인 2003년 1년 동안 도말 양성 객담 중 $26 \%(220 / 826)$ 에서 NTM이 분리되었고, 도말 양성 환 자 중 $23 \%(70 / 299)$ 가 NTM 폐질환으로 진단되었는 
데, 이는 1997 년부터 2001년까지의 같은 기관에서의 조사에서 밝혀진 10-11\% ${ }^{8}$ 에 비하여 높은 비율이다. 이는 본 연구기관이 삼차의료기관의 특성 상 NTM 폐질환으로 진단되거나 NTM 폐질환이 의심되어 의 뢰되는 환자의 비율이 최근 증가하고 있다는 특성과 관련이 있을 것이며, 이러한 비율을 국내에서 일반화 할 수는 없을 것이다. 객담 도말 양성 환자에서 폐결 핵과 NTM 폐질환의 감별에 TB-PCR 검사가 얼마나 도움이 될 수 있을 지 또한 비용-효과적인 측면이 어 떠한지에 대해서는 향후 국내에서 추가적인 연구가 필요하리라 사료된다. 또한 최근에는 $\mathrm{TB}-\mathrm{PCR}$ 검사 처럼 단순히 결핵균과 NTM을 구별하는 것이 아니라, 결핵균과 NTM을 구별하면서 NTM의 균 동정까지 한 번에 가능한 duplex PCR과 같은 새로운 진단법이 개발되어 임상 검체에서 분리된 균주에 적용하였을 때 기존의 균 동정법과 매우 높은 일치율을 보고하고 있다 ${ }^{22}$. 이러한 새로운 진단법을 도말 양성 검체에 직 접 적용하는 것에 대한 임상적 유용성도 향후 연구가 필요하리라 사료된다.

결론적으로 객담 항산균 도말 양성을 보이는 환자 에서 객담 또는 기관지 세척액 $\mathrm{TB}-\mathrm{PCR}$ 검사는 국내 에서도 폐결핵과 NTM 폐질환을 구별하는데 임상적 유용성이 있을 것으로 사료된다.

\section{요 약}

배 경 :

객담 항산균 도말 검사는 저렴하고 간편한 검사이 며, 검사 결과를 빨리 얻을 수 있다는 장점이 있지만, 결핵균과 NTM을 구별하지 못한다는 제한점이 있다. 외국에서는 도말 양성 환자에서 폐결핵과 NTM 폐질 환을 구별하기 위하여 TB-PCR 검사가 권장되고 있 다. 본 연구는 국내에서도 객담 도말 양성 환자에서 객담 또는 기관지 세척액의 $\mathrm{TB}-\mathrm{PCR}$ 검사가 폐결핵 과 NTM 감염의 감별 진단에 유용한가를 알아보고자 하였다.

대상 및 방법 :

2003년 1월 1일부터 2003년 12월 31일까지 1년간 진단검사의학과 임상미생물검사실로 항산균 도말 및
배양검사가 의뢰된 객담 검체 중 도말과 배양이 모두 양성인 826건의 객담 검체를 연구대상으로 하였고, 이 검체가 분리된 환자 299 명의 의무기록과 방사선학적 소견을 후향적으로 조사하였다.

결 과 :

결핵균이 분리된 객담은 606건(73.4\%)이었고 NTM 이 분리된 객담은 220 건(26.6\%)이었다. 299명의 환자 중 결핵균이 분리된 폐결핵 환자는 229 명(76.6\%)이었 고, NTM이 분리된 환자는 70명(23.4\%)이었으며 모두 임상적 의의가 있는 NTM 폐질환 환자였으며, 원인균 은 M. avium complex 38명(54.3\%), M. abscessus 26 명(37.1\%), 기타 6명 등이었다. 폐결핵 환자 229명 중 112 명(48.9\%)와 NTM 폐질환 환자 70명 중 51명 (72.9\%)에서 객담 또는 기관지 세척액을 이용한 TB$\mathrm{PCR}$ 검사가 시행되었다. 검사를 시행한 폐결핵 환자 112 명 중 99 명(88.4\%)에서 $\mathrm{TB}-\mathrm{PCR}$ 검사가 양성을 보였고, NTM 폐질환 환자는 모두 음성을 보였다 (p< 0.001). 객담 도말 양성 환자에서 객담 또는 기관지 세 척액의 $\mathrm{TB}-\mathrm{PCR}$ 검사 양성 반응이 폐결핵을 예측하 는 민감도와 특이도는 각각 $88.4 \%(99 / 112)$ 와 $100 \%$ (51/51)였고, 양성 예측치는 100\%(99/99) 그리고 음성 예측치는 $79.7 \%(51 / 64)$ 였다

\section{결 론 :}

객담 항산균 도말 양성을 보이는 환자에서 객담 또 는 기관지 세척액 $\mathrm{TB}-\mathrm{PCR}$ 검사는 국내에서도 폐결 핵과 NTM 폐질환을 구별하는데 임상적 유용성이 있 을 것으로 사료된다.

\section{참 고 문 헌}

1. American Thoracic Society. Diagnostic Standards and Classification of Tuberculosis in Adults and Children. Am J Respir Crit Care Med 2000;161: 1376-95.

2. World Health Organization. Treatment of Tuberculosis: Guidelines for national programmes. 3rd ed. Geneva, Switzerland, World Health Organization, 2003.

3. Korean Academy of Tuberculosis and Respiratory Diseases. Diagnostic standards of pulmonary tuberculosis, 1997. Tuberc Respir Dis 1997;44:1447-53.

4. Schluger NW. Changing approaches to the diagnosis 
of tuberculosis. Am J Respir Crit Care Med 2001; 164:2020-4.

5. American Thoracic Society. Rapid diagnostic tests for tuberculosis: what is the appropriate use? Am J Respir Crit Care Med 1997;155:1804-14.

6. Centers for Disease Control and Prevention. Update: Nucleic acid amplification tests for tuberculosis. MMWR Morb Mortal Wkly Rep 2000;49: 593-4.

7. Korean Center for Disease Control and Prevention. Guidelines for the control of tuberculosis 2004. Seoul, 2004.

8. Koh WJ, Kwon OJ, Yu CM, Jeon K, Suh GY, Chung MP, et al. Recovery Rate of Nontuberculous Mycobacteria from Acid-Fast-Bacilli Smear-Positive Sputum Specimens. Tuberc Respir Dis 2003;54:22-32.

9. Kim CS, Son HD, Park MR, Seo JY, Cho DI, Rheu NS. The Usefulness of PCR Study in AFB Smear Negative Patients on Admission. Tuberc Respir Dis 1997;44:1001-10.

10. Kyong TY, Lee JH, Chae GS, Kim DK, Mo EK, Park MJ, et al. Cummulative Positive Rate of Consecutive Sputum Polymerase Chain Reaction in Pulmonary Tuberculosis. Korean J Med 1998;55: 1049-56.

11. Baek SH, Lee JM, Kang MJ, Son JW, Lee SJ, Kim DK, et al. How Reliable is Sputum PCR Test in the Diagnosis of Pulmonary Tuberculosis When Sputum Smear is Negative? Tuberc Respir Dis 2001;50:222-8.

12. Park MH, Choi $\mathrm{CH}$, Kim NJ. The Diagnostic Value of Bronchoalveolar lavage fluid microscopic study and PCR in Pulmonary tuberculosis. Tuberc Respir Dis 1996;43:128-37.

13. Mo EK, Kyung TY, Kim DG, Park MJ, Lee MG, Hyun IG, et al. The Clinical Utility of Polymerase Chain Reaction in the Bronchoalveolar Lavage Fluid for the Detection of Mycobacteria. Tuberc Respir Dis 1998;46:519-28.
14. Lee J, Kim Y, Park J, Ko W, Yang D, Kim S, et al. Clinical Utility of Bronchial Washing PCR for IS6110 and Amplicor for the Rapid Diagnosis of Active Pulmonary Tuberculosis in Smear Negative Patients. Tuberc Respir Dis 2001;50:213-21.

15. Lee H, Park HJ, Cho SN, Bai GH, Kim SJ. Species identification of mycobacteria by PCR-restriction fragment length polymorphism of the rpoB gene. $\mathrm{J}$ Clin Microbiol 2000;38:2966-71.

16. Koh WJ, Kwon OJ, Ham HS, Suh GY, Chung MP, $\mathrm{Kim} \mathrm{H}$, et al. Clinical significance of nontuberculous mycobacteria isolated from respiratory specimens. Koréan J Internal Med 2003;65:10-21.

17. Piersimoni C, Scarparo C. Relevance of commercial amplification methods for direct detection of $M y$ cobacterium tuberculosis complex in clinical samples. J Clin Microbiol 2003;41:5355-65.

18. Centers for Disease Control and Prevention. Nucleic acid amplification tests for tuberculosis. MMWR Morb Mortal Wkly Rep 1996;45:950-2.

19. Chan W, Chia M, Lee LK, Macfadyen DM. Bacteriological measures for the detection of cases of pulmonary tuberculosis. Bull World Health Organ 1971;45:551-8.

20. Blair EB, Brown GL, Tull AH. Computer files and analyses of laboratory data from tuberculosis patients. II. Analyses of six years' data on sputum specimens. Am Rev Respir Dis 1976;113:427-32.

21. Levy H, Feldman C, Sacho H, van der Meulen H, Kallenbach J, Koornhof $\mathrm{H}$. A reevaluation of sputum microscopy and culture in the diagnosis of pulmonary tuberculosis. Chest 1989;95:1193-7.

22. Kim BJ, Hong SK, Lee KH, Yun YJ, Kim EC, Park YG, et al. Differential identification of Mycobacterium tuberculosis complex and nontuberculous mycobacteria by duplex PCR assay using the RNA polymerase gene (rpoB). J Clin Microbiol 2004;42: 1308-12. 